\title{
Article
}

\section{CD8 and CD4 T Cell Populations in Human Kidneys}

\author{
Carlos van der Putten ${ }^{1,2, *, \dagger}$, Ester B.M. Remmerswaal ${ }^{1,2,+}$, , Matty L. Terpstra ${ }^{1,2, \dagger}$, Nelly D. van der Bom ${ }^{1,2}$, \\ Jesper Kers ${ }^{3}$, Ineke J.M. ten Berge ${ }^{1,2}$, Suzanne E. Geerlings ${ }^{4}$, René A.W. van Lier ${ }^{5}$, Frederike J. Bemelman ${ }^{1,2,+}$ \\ and Michiel C. van Aalderen ${ }^{1,2,+}$
}

check for updates

Citation: van der Putten, C.; Remmerswaal, E.B.M.; Terpstra, M.L.; van der Bom, N.D.; Kers, J.; ten Berge, I.J.M.; Geerlings, S.E.; van Lier, R.A.W.; Bemelman, F.J.; van Aalderen, M.C. CD8 and CD4 T Cell Populations in Human Kidneys. Cells 2021, 10, 288. https://doi.org/10.3390/cells10020288

Academic Editors: Alexander E. Kalyuzhny, Maciej Lech and Jörg Hamann

Received: 14 November 2020

Accepted: 27 January 2021

Published: 1 February 2021

Publisher's Note: MDPI stays neutral with regard to jurisdictional claims in published maps and institutional affiliations.

Copyright: (c) 2021 by the authors. Licensee MDPI, Basel, Switzerland. This article is an open access article distributed under the terms and conditions of the Creative Commons Attribution (CC BY) license (https:/ / creativecommons.org/licenses/by/ $4.0 /)$.
1 Department of Experimental Immunology, Amsterdam institute for Infection \& Immunity, Amsterdam UMC, University of Amsterdam, 1105AZ Amsterdam, The Netherlands; e.b.remmerswaal@amsterdamumc.nl (E.B.M.R.); Matty.Terpstra@amsterdamumc.nl (M.L.T.); n.d.baylon@amsterdamumc.nl (N.D.v.d.B.); r.j.tenberge@amsterdamumc.nl (I.J.M.t.B.); f.j.bemelman@amsterdamumc.nl (F.J.B.); M.C.vanaalderen@amsterdamumc.nl (M.C.v.A.)

2 Division of Internal Medicine, Department of Nephrology, Renal Transplant Unit, Amsterdam Infection \& Immunity Institute (AI\&II), Amsterdam UMC, University of Amsterdam, 1105AZ Amsterdam, The Netherlands

3 Department of Pathology, Leiden University Medical Center, 2300 RC Leiden, The Netherlands; j.kers@amsterdamumc.nl

4 Department of Internal Medicine, Infectious Diseases, Amsterdam Infection \& Immunity Institute (AI\&II), Amsterdam UMC, University of Amsterdam, 1105AZ Amsterdam, The Netherlands; s.e.geerlings@amsterdamumc.nl

5 Sanquin Research and Landsteiner laboratory, 1066CX Amsterdam, The Netherlands; r.vanlier@amsterdamumc.nl

* Correspondence: c.vanderputten@amsterdamumc.nl

+ Authors contributed equally.

Abstract: Background: At border sites, and in internal organs, tissue resident memory $\mathrm{T}$ cells $\left(\mathrm{T}_{\mathrm{RM}}\right)$ contribute to the immune barrier against pathogens like viruses, bacteria, fungi, and cancer. However, information on the presence and function of these cells in the human kidney is scant. In order to better understand the T cell-mediated immunological defense in this organ, we aimed to determine phenotypic and functional aspects of CD8 and CD4 T cells present in healthy and allograft kidney tissue. Methods: Using multichannel flow cytometry, we assessed the phenotype and function of T cells in healthy renal tissue samples $(n=5)$ and kidney allograft tissue $(n=7)$ and compared these aspects to T cells in peripheral blood from healthy controls $(n=13)$. Results: Kidney tissue samples contained substantial amounts of CD8 and CD4 T cells. In contrast to the circulating cells, kidney T cells frequently expressed CD69 and CD103, and were more often actively cycling. Furthermore, nearly all kidney T cells expressed CXCR3, and often expressed CXCR6 compared to T cells in the circulation. Markedly, kidney T cells produced greater quantities of IFN $\gamma$ than circulating cells and were frequently polyfunctional. Conclusion: Functional $\mathrm{T}$ cells with the characteristic traits of $\mathrm{T}_{\mathrm{RM}}$ reside in human kidney tissues. These cells are more often actively cycling and frequently express CXCR3 and CXCR6.

Keywords: tissue-resident lymphocytes; T-cells; CD8; CD4; CD69; CD103; kidney; allograft

\section{Introduction}

Resident memory $\mathrm{T}$ cells $\left(\mathrm{T}_{\mathrm{RM}}\right)$ persist in tissues to provide a long-term localized defense against pathogens. In contrast to recirculating $\mathrm{T}$ cells, $\mathrm{T}_{\mathrm{RM}}$ populations cannot be detected in peripheral blood, and differ significantly from recirculating $\mathrm{T}$ cell populations with regard to their phenotype, function, and metabolism [1]. Indeed, this is not surprising considering the fact that different organ systems, like the lungs, are exposed to higher loads of different pathogens than is the case for the circulation, which is generally isolated from the outside world [2]. 
Tissue retention of $\mathrm{T}_{\mathrm{RM}}$ persists for years and is mediated by mechanisms that involve the Sphingosine-1-phosphate receptor 1 (S1PR1)-sphingosine 1-phosphate (SP1) axis. S1PR1 is a receptor expressed by $\mathrm{T}$ cells that mediates egression from secondary lymphoid organs upon binding to the bioactive signaling molecule SP1, which is an important mediator of $\mathrm{T}$ cell trafficking. This axis can be interrupted by CD69, a membrane-bound c-type lectin that antagonizes S1PR1 expression, thus mediating retention. Furthermore, in mice S1PR1 expression is induced by the transcription factor Krüppel-like Factor 2 (KLF2), which was found to be downregulated in $\mathrm{T}_{\mathrm{RM}}$, thereby also inhibiting lymphocyte egress [3]. In turn, downregulation of KLF2 was shown to be mediated by the transcription factor homolog of Blimp1 in T cells (Hobit), which is expressed in a $\mathrm{T}_{\mathrm{RM}^{-}}$-specific manner in murine $\mathrm{T}$ cells [4]. Furthermore, some $\mathrm{T}_{\mathrm{RM}}$ also express $\mathrm{CD} 103$ (integrin $\alpha \mathrm{E}$ ), whereby $\mathrm{T}_{\mathrm{RM}}$ can be identified using CD69 and CD103 expression [1].

While knowledge on $\mathrm{T}_{\mathrm{RM}}$ phenotype and function is increasing for various human tissues, little is known about these aspects in the kidney. Here, $\mathrm{T}$ cells are exposed to a distinct set of pathogens such as bacteria ascending from the lower urinary tract and renotropic viruses like polyomavirus $\mathrm{BK}(\mathrm{BKPyV})$. Indeed, we recently described how human kidneys contain a subset of T cells expressing CD69 and/or CD103, amongst which there are CD8 T cells specifically targeting the BKPyV proteins virion protein 1 (VP1) and large $\mathrm{T}$ antigen (LTAG) protein [5]. We, and others, also demonstrated the presence of CD69/CD103-expressing mucosa-associated invariant T (MAIT) cells in kidney tissue [6,7].

To better understand what kind of $\mathrm{T}$ cells constitute the localized immune response in this organ, we used multichannel flowcytometry to investigate the phenotype and function of kidney $\mathrm{T}_{\mathrm{RM}} \mathrm{s}$, isolated from donor kidney material of renal transplant recipients (RTRs) and from healthy kidney tissue adjacent to renal clear cell carcinomas, to see how these populations compare to $\mathrm{T}$ cell populations in the circulation.

We found that human kidney tissue holds substantial amounts of CD4 and CD8 T cells expressing just CD69, CD69 and CD103, or none of these markers. We found that $\mathrm{CD}^{-} 9^{-} \mathrm{CD} 103^{-}$cells in kidney tissue differ substantially from $\mathrm{T}$ cells in the circulation and may represent a $\mathrm{T}_{\mathrm{RM}}$ population lacking the canonical $\mathrm{T}_{\mathrm{RM}}$ markers. Furthermore, we show that kidney $\mathrm{T}$ cells are more often actively cycling, as judged by increased expression of Ki-67, when compared to blood. We also found that CD8 and CD4 T cells in kidney tissue nearly always express CXCR3 and often express CXCR6. These findings implicate a role for these chemokine receptors in the attraction and maintenance of kidney-resident memory $\mathrm{T}$ cell populations.

\section{Materials and Methods}

\subsection{Patients and Samples}

Samples were obtained from the Biobank Renal Diseases of the Amsterdam UMC location AMC. In this Biobank, patient samples, such as blood and kidney tissue, are collected and stored from healthy living kidney donors and RTRs that are followed before and after kidney transplantation. This study was conducted according to the principles outlined in the Declarations of Helsinki and Istanbul and all participants provided written informed consent prior to enrollment in the Biobank. Additionally, residual tissue from patients who underwent tumor nephrectomy (kidney tissue distant from the tumor) was donated by the Department of Pathology and also stored in the Biobank. These tissues were processed anonymously according to the Federation of Dutch Medical Scientific Societies' Code of Conduct (Human Tissue and Medical Research: Code of Conduct for Responsible Use, 2011 www.federa.org).

\subsection{Peripheral Blood Mononuclear Cells (PBMCs)}

Blood samples were obtained from cytomegalovirus (CMV)-seronegative healthy controls (living kidney donors prior to surgery, $n=13$ ). Characteristics of the participants in this study are displayed in Table 1. PBMCs were isolated from sodium heparin blood by standard density gradient centrifugation and subsequently cryopreserved until the day of analysis. 
Table 1. Demographics.

\begin{tabular}{|c|c|c|c|}
\hline & Healthy Kidneys & Kidney Transplants & Healthy Donors \\
\hline & $n=5$ & $n=7$ & $n=13$ \\
\hline Sex, men $(\%)$ & $60 \%$ & $57 \%$ & $62 \%$ \\
\hline Age in years, median (range) & $71(69-78)$ & $55(26-71)$ & $57(33-70)$ \\
\hline Diabetes mellitus (\%) & Unknown & $14 \%$ & $0 \%$ \\
\hline $\begin{array}{c}\text { Original renal disease of the allograft } \\
\text { recipient }(\%)\end{array}$ & \multirow{7}{*}{$\mathrm{N} / \mathrm{A}$} & & \multirow{7}{*}{$\mathrm{N} / \mathrm{A}$} \\
\hline - FSGS & & 2 & \\
\hline - Renovascular & & 2 & \\
\hline - IgAN & & 1 & \\
\hline - ADPKD & & 1 & \\
\hline $\begin{array}{l}\text { - Idiopathic membranous } \\
\text { glomerulopathy }\end{array}$ & & 1 & \\
\hline - Unknown & & - & \\
\hline \multicolumn{4}{|l|}{$\begin{array}{c}\text { Cause of transplant failure as reported in } \\
\text { the medical file }(\%)\end{array}$} \\
\hline - Rejection & \multirow{3}{*}{$\mathrm{N} / \mathrm{A}$} & 5 & \multirow{3}{*}{$\mathrm{N} / \mathrm{A}$} \\
\hline- ATN & & 1 & \\
\hline - BK & & 1 & \\
\hline $\begin{array}{l}\text { Months since renal transplantation, } \\
\text { median (range) }\end{array}$ & $\mathrm{N} / \mathrm{A}$ & $14(0.3-60)$ & $\mathrm{N} / \mathrm{A}$ \\
\hline $\begin{array}{l}\text { Number of immunosuppressive agents at } \\
\text { time of sample collection, median (range) }\end{array}$ & $\mathrm{N} / \mathrm{A}$ & $2(1-4)$ & $\mathrm{N} / \mathrm{A}$ \\
\hline Donor type (living/NHB/HB) & $\mathrm{N} / \mathrm{A}$ & $3 ; 4 ; 0$ & $\mathrm{~N} / \mathrm{A}$ \\
\hline
\end{tabular}

N/A: not applicable; FSGS: focal segmental glomerulosclerosis; IgAN: IgA nephropathy; ADPKD: autosomal dominant polycystic kidney disease; ATN: acute tubular necrosis; BK: polyomavirus BK-induced nephropathy.

\subsection{Kidney Tissue}

Healthy kidney tissue samples $(n=5)$ were obtained from kidneys that were surgically removed due to renal cell carcinoma (distant nontumorous tissue from the contralateral pole of the kidney) and transplant kidney tissue $(n=7)$ was obtained from explanted renal allografts after transplant failure. These samples are referred to as healthy and transplant kidney samples, respectively. Slices of kidney cortex were chopped into 1-mm cubes with the McIlwain Tissue Chopper (Ted Pella, Redding, CA, USA), transferred to $50 \mathrm{~mL}$ tubes and washed with cold PBS until no blood was visibly present and the supernatant was clear. Preheated $\left(37^{\circ} \mathrm{C}\right)$ digestion medium was added, $40 \mathrm{~mL}$ per $10 \mathrm{~g}$ of tissue (DNAse I type IV (50 KU/mL) (Sigma Aldrich, Zwijndrecht, The Netherlands), collagenase type IV $(0.5 \mathrm{mg} / \mathrm{mL})$ (Wortington Biochemical, Lakewood, NJ, USA), BSA (60 mg/mL) (Sigma Aldrich), $20 \mu \mathrm{L} / \mathrm{mL}$ fetal calf serum (FCS, VWR International BV, Amsterdam, The Netherlands), TRIS (0.025 M) (Merck BV, Amsterdam, The Netherlands), penicillin streptomycin (Biochrom GMBH, Berlin, Germany) in HBSS (Westburg BV, Leusden, The Netherlands)), and incubated in a shaker for $20 \mathrm{~min}$ at $37^{\circ} \mathrm{C}$. The warm suspension was transferred to a C-tube (Miltenyi, Bergisch Gladbach, Germany) and subjected to the M_spleen_04.01 program on the GentleMacs (Miltenyi). The digestion medium was deactivated with cold PBS and the resulting cell suspension passed through a cell strainer to obtain a single cell suspension, which was subjected to standard density gradient centrifugation according to manufacturer's protocol (Lymphoprep, Abbott Diagnostics Technologies AS, Oslo, Norway). The isolated mononuclear cells (kidney MNCs) were 
cryopreserved until the day of analysis in IMDM supplemented with 20\% FCS, 0.00036 $v / v \% \beta$-mercaptoethanol, $5 \%$ DMSO, penicillin and streptomycin.

\subsection{Flow Cytometry}

Measurements were performed on an LSRFortessa flow cytometer (BD Biosciences). For each sample, $2 \times 106$ PBMCs or $0.5 \times 106$ to $10 \times 106$ kidney MNCs were analyzed. The volume of each staining reaction was relative to the number of cells and the antibody concentrations remained constant. Cells were incubated with the surface antibodies (Supplemental Table S1) for $30 \mathrm{~min}$ at $4{ }^{\circ} \mathrm{C}$ in the dark. Dead cells were excluded using the fixable viability dye eFluor455UV (eBioscience Inc., Thermo Fisher Scientific, San Diego, CA, USA). Monoclonal antibodies with intracellular targets (Supplemental Table S1) were added after the fixation and permeabilization of the cells using the FoxP3/Transcription Factor Staining Set (eBioscience Inc.). Published methods for flow cytometry and cell sorting for immunological purposes were followed [8]. The gating strategy used for the phenotypic analysis can be found in Supplemental Figure S1. We have previously shown that none of the markers analyzed were affected by the digestion method used to isolate kidney MNCs [7].

Tissue sample limitations resulted in the exclusion of samples from certain panels. CD3+ cell counts analyzed per sample in healthy PBMCs, healthy kidney MNCs and TX kidney can be found in Figure S3. MNCs Samples were only analyzed when they contained over $50 \%$ live cells within the lymphogate, as assessed by the viability dye, and CD69/CD103 based T cell-subsets were only further characterized if their total cell count exceeded 50 .

\subsection{Stimulation Assay}

PBMC and kidney MNC were stimulated as previously described [7,9]. PBMCs and kidney MNCs were thawed in the presence of DNAse I $(200 \mathrm{KU} / \mathrm{mL})$, washed, and allowed to recover overnight in untreated, round-bottom, 96-well plates (Corning) in culture medium (RPMI supplemented with $10 \%$ FCS and penicillin streptomycin) at a concentration of $20 \times 106 / \mathrm{mL}(100 \mu \mathrm{L} /$ well $)$.

The next morning, phorbol 12-myristate 13-acetate (PMA, $10 \mathrm{ng} / \mathrm{mL}$; Sigma Aldrich) and ionomycin ( $1 \mu \mathrm{g} / \mathrm{mL}$; Sigma Aldrich) were added to stimulate the cells. Medium alone was added as the negative control. All incubations were performed in culture medium in the presence of $\alpha \mathrm{CD} 28$ (clone 15E8; $2 \mu \mathrm{g} / \mathrm{mL}$ ), $\alpha \mathrm{CD} 29$ (clone TS 2/16; $1 \mu \mathrm{g} / \mathrm{mL}$ ), brefeldin A $(10 \mu \mathrm{g} / \mathrm{mL}$, Invitrogen), and GolgiStop (BD Biosciences) in a final volume of $200 \mu \mathrm{L}$ for $4 \mathrm{~h}$ at $37^{\circ} \mathrm{C}$ and $5 \% \mathrm{CO}_{2}$.

Subsequently, the cells were incubated for $30 \mathrm{~min}$ with the surface antibodies (Supplemental Table S2). Dead cells were excluded using fixable viability dye eFluor780 (eBioscience Inc., Thermo Fisher Scientific, San Diego, CA, USA). Monoclonal antibodies for intracellular staining (Table S1) were added after fixation and permeabilization of the cells using the Cytofix/Cytoperm Reagent Set (BD Biosciences). Cells were washed twice and analyzed on an LSRFortessa flow cytometer. The gating strategy used in the functional analysis can be found in Supplemental Figure S2. To determine the polyfunctionality of each $T$ cell subset, the average number of functions of each population was calculated using the following formula: (([percentage of cells producing 1 cytokine $\left.]^{*} 1\right)+($ [percentage of cells producing 2 cytokines] $\left.\left.]^{*}\right)+(\text { [percentage of cells producing } 3 \text { cytokines }]^{*} 3\right)+($ [percentage of cells producing 4 cytokines] $\left.{ }^{*} 4\right)+($ [percentage of cells producing all 5 cytokines]*5)) $/ 100$.

\subsection{Data Analysis}

Data were analyzed using FlowJo version 10 (FlowJo, Ashland, OR, USA). All graphs and figures were created using Graphpad Prism version 8.00 for Windows (GraphPad Software, La Jolla, CA, USA). The same program was also used for the statistical analyses of the data. The nonparametric Mann-Whitney-U test was used to determine significance 
of unpaired samples. To compare paired samples, the Wilcoxon signed rank test was used. $p$-values $<0.05$ were considered statistically significant.

\section{Results}

\subsection{Distinct Expression of CD8 and/or CD4 and Markers of Tissue Residency by T Cells in} Healthy Kidney Tissue

First, we compared the expression of CD4 and CD8 by CD3-positive T cells in peripheral blood to cells detected in healthy kidney tissue. $\mathrm{CD}^{-} \mathrm{CD}^{+}(\mathrm{CD} 8) \mathrm{T}$ cells were significantly more often detected in kidney tissue than in blood ((median) $25 \%$ vs. $38 \%$ ) (Figure 1a). In contrast, $\mathrm{CD} 4^{+} \mathrm{CD}^{-}(\mathrm{CD} 4) \mathrm{T}$ cells were detected in higher frequencies in blood than in kidney tissue ((70\% vs. 52\%) Figure 1a). Overall, CD4 T cells were seen more frequently in healthy kidney tissue than CD8 T cells (Figure 1b).

a

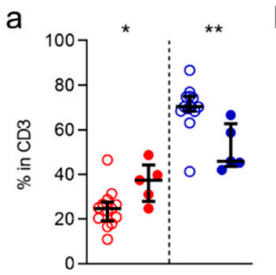

b

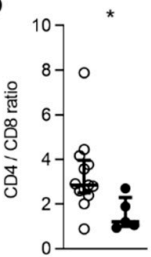

鸽喜

$\begin{array}{ll} & \\ & 0 \\ 0 & 0 \\ 0 & 0 \\ 0 & 0 \\ 0 & 0 \\ 0 & 0\end{array}$

$\bigcirc \mathrm{PB}(n=13)$

- Healthy kidney MNC $(n=5)$ c

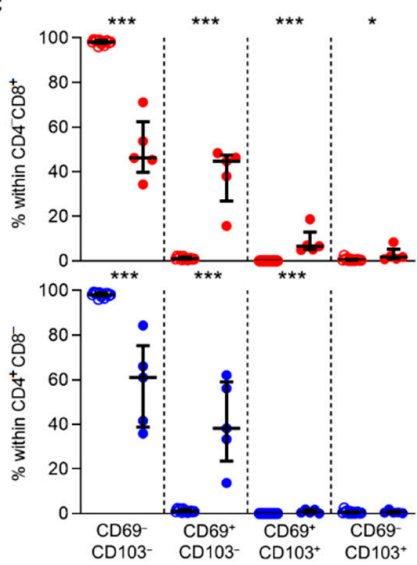

d

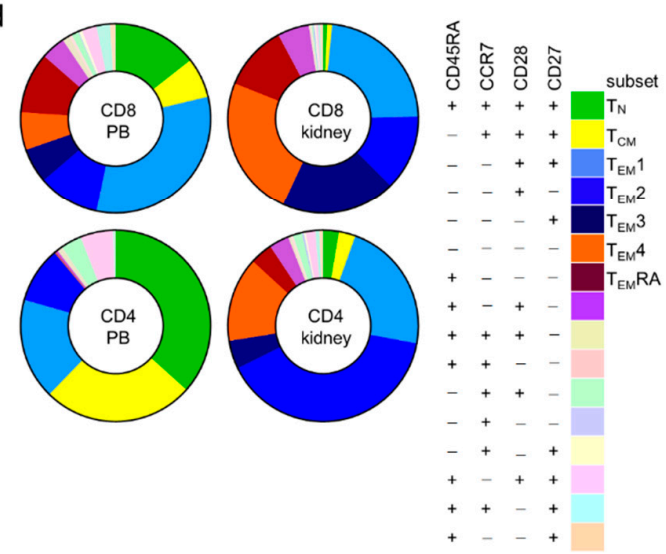

Figure 1. Kidney-derived $\mathrm{T}$ cells differ in $\mathrm{CD} 4 / \mathrm{CD} 8$ distribution, contain $\mathrm{TrM}$ and have a different memory-profile than PB T cells. (a) Percentage of $\mathrm{CD} 4^{-} \mathrm{CD} 8^{+}(\mathrm{CD} 8)$ and $\mathrm{CD} 4^{+} \mathrm{CD} 8^{-}(\mathrm{CD} 4) \mathrm{T}$ cells within $\mathrm{CD}^{+} \mathrm{CD}^{+} 5^{+}$single-cell live lymphocytes in peripheral blood (PB) and healthy kidney MNC (median with IQR in black). (b) CD4/CD8 ratio within PB and healthy kidney-derived T cells. (c) Distribution of CD69/CD103 based subsets within CD8 and CD4 T cells (median with IQR in black) derived from PB and healthy kidney. (d) Expression patterns of CD27, CD45RA, CCR7 and CD28 within CD8 and CD4 T cells from PB and healthy kidney (median). Mann-Whitney U-test was used for statistical comparison. Only significant $p$-values are displayed: ${ }^{*} p<0.05,{ }^{* *} p \leq 0.01,{ }^{* * *} p \leq 0.001$.

Next, we investigated the expression of the tissue-residency markers, CD69 and CD103, in CD8 and CD4-defined T cell subsets. As expected, CD69 and CD103 were virtually not expressed by cells in peripheral blood (Figure 1c). In healthy tissue, the $\mathrm{CD} 69^{-} \mathrm{CD} 103^{-}$, $\mathrm{CD} 9^{+} \mathrm{CD} 103^{-}, \mathrm{CD} 9^{+} \mathrm{CD} 103^{+}$, and $\mathrm{CD} 69^{-} \mathrm{CD} 103^{+}$phenotypes were expressed by, $46 \%$, $45 \%, 6.6 \%$, and $1.8 \%$ of CD 8 T cells, $61 \%, 38 \%, 0.44 \%$, and $0.43 \%$ of CD4 T cells, respectively (Figure 1c). 
In conclusion, CD8, but particularly CD4 T cells were detected in substantial numbers in healthy human kidney tissue. Furthermore, expression of CD69 and CD103, markers of tissue-residency, was detected primarily among $\mathrm{T}$ cells found in healthy tissue and not in blood.

\subsection{Different Expression Patterns of Common Subset-Denominating Markers by T Cells in Healthy Kidney Tissue}

CD45RA, a tyrosine phosphatase, CCR7, a chemokine receptor known to mediate T cell trafficking to secondary lymphoid organs, and CD28 and CD27, both costimulatory receptors strongly involved in $\mathrm{T}$ cell activation, are all markers traditionally used to identify functional $\mathrm{T}$ cell subsets $[10,11]$. We wanted to investigate to what extent the distribution of these subsets in blood differ from the distribution in kidney tissue. As expected, the largest CD8 $\mathrm{T}$ cell subsets detected in the circulation (i.e., those concerning $\geq 5 \%$ of the total population) were those with a CD45RA ${ }^{+} \mathrm{CCR} 7^{+} \mathrm{CD} 28^{+} \mathrm{CD} 27^{+}$(naive $\mathrm{T}$ cells or $\mathrm{T}_{\mathrm{N}}$, (median) $13 \%$ ), CD45RA ${ }^{-} \mathrm{CCR}^{+} \mathrm{CD} 28^{+} \mathrm{CD}^{2} 7^{+}$(central-memory $\mathrm{T}$ cells or $\mathrm{T}_{\mathrm{CM}}, 6 \%$ ), $\mathrm{CD}^{2}$ RA ${ }^{-} \mathrm{CCR}^{-}{ }^{-} \mathrm{CD} 28^{+} \mathrm{CD}^{2} 7^{+}\left(\mathrm{T}_{\mathrm{EM}} 1,30 \%\right), \mathrm{CD} 45 \mathrm{RA}^{-} \mathrm{CCR}^{-} \mathrm{CD}^{2} 8^{+} \mathrm{CD}^{2} 7^{-}\left(\mathrm{T}_{\mathrm{EM}} 2,10 \%\right)$, $\mathrm{CD}^{2} 5 \mathrm{RA}^{-} \mathrm{CCR}^{-} \mathrm{CD}^{-} 8^{-} \mathrm{CD}^{2} 7^{+}\left(\mathrm{T}_{\mathrm{EM}} 3,6 \%\right), \mathrm{CD}^{3} 5 \mathrm{RA}^{-} \mathrm{CCR}^{-} \mathrm{CD}^{-} 8^{-} \mathrm{CD}^{-} 7^{-}\left(\mathrm{T}_{\mathrm{EM}} 4,6 \%\right)$

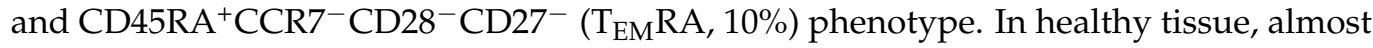
no $(0.6 \%)$ CD8 $\mathrm{T}$ cells were detected with a $\mathrm{T}_{\mathrm{N}}$ phenotype and only few $(0.8 \%)$ displayed a $\mathrm{T}_{\mathrm{CM}}$ phenotype. In contrast, CD8 $\mathrm{T}$ cells detected in healthy kidney tissue were composed of considerable $\mathrm{T}_{\mathrm{EM}} 1-(22 \%), \mathrm{T}_{\mathrm{EM}} 2-(12 \%), \mathrm{T}_{\mathrm{EM}} 3-(18 \%), \mathrm{T}_{\mathrm{EM}} 4-(23 \%)$, and $\mathrm{T}_{\mathrm{EM}} \mathrm{RA}(11 \%) \mathrm{T}$ cell populations (Figure $1 \mathrm{~d}$ and Figure $\mathrm{S} 4$ ).

When looking at CD4 T cells in blood, the largest populations were those expressing a $\mathrm{T}_{\mathrm{N}^{-}}(35 \%), \mathrm{T}_{\mathrm{CM}^{-}}(25 \%), \mathrm{T}_{\mathrm{EM}} 1-(16 \%), \mathrm{T}_{\mathrm{EM}^{2-}}(9 \%)$, and a population with a not otherwise specified $\mathrm{CD} 45 \mathrm{RA}^{+} \mathrm{CCR} 7^{-} \mathrm{CD}^{2} 8^{+} \mathrm{CD} 27^{+}$phenotype $(0.4 \%)$ (Figure $1 \mathrm{~d}$ and Figure S4). In healthy kidney tissue, few CD4 $\mathrm{T}$ cells expressed a $\mathrm{T}_{\mathrm{N}^{-}}(3 \%)$ or a $\mathrm{T}_{\mathrm{CM}^{-}}(3 \%)$ phenotype. Instead, a substantial number of cells with a $\mathrm{T}_{\mathrm{EM}} 1-(22 \%), \mathrm{T}_{\mathrm{EM}} 2-(40 \%)$, or $\mathrm{T}_{\mathrm{EM}} 4-(14 \%)$ phenotype were detected in healthy tissue (Figure $1 \mathrm{~d}$ and Figure S4).

In conclusion, the distribution of CD45RA/CCR7/CD28/CD27-defined CD8 and CD4 $\mathrm{T}$ cell subsets differs substantially between blood and healthy kidney tissue.

\subsection{CD8 and CD4 T Cells in Healthy Human Kidney Tissue More Often Comprise Actively Cycling Cells}

Next, we investigated whether there are differences in the expression of markers typical of a cytotoxic effector-memory profile, between CD8 and CD4 T cell populations in blood and kidney tissue.

First, we looked at the expression of the T-box transcription factors T-bet and eomesodermin (Eomes). These transcriptional regulators are directly involved in generating acute phase effector cells, inducing expression of molecules like interferon- $\gamma$ and granzyme B, and in the generation of secondary memory responses. As expected, expression of T-bet was frequent among circulatory CD8 T cells (54\%), while circulatory CD4 T cells rarely expressed this transcription factor (13\%). Interestingly, for CD4 T cells, T-bet expression was significantly higher among $\mathrm{T}$ cells detected in healthy kidney tissue than in the circulation (53\% vs 13\%). Eomes expression was also detected frequently among circulatory CD8 T cells (59\%), while again being rare among circulatory CD4 T cells $(15 \%)$.

However, Eomes expression was more frequent among CD4 T cells in kidney tissue $(32 \%)$ than in blood (Figure 2a,b). 

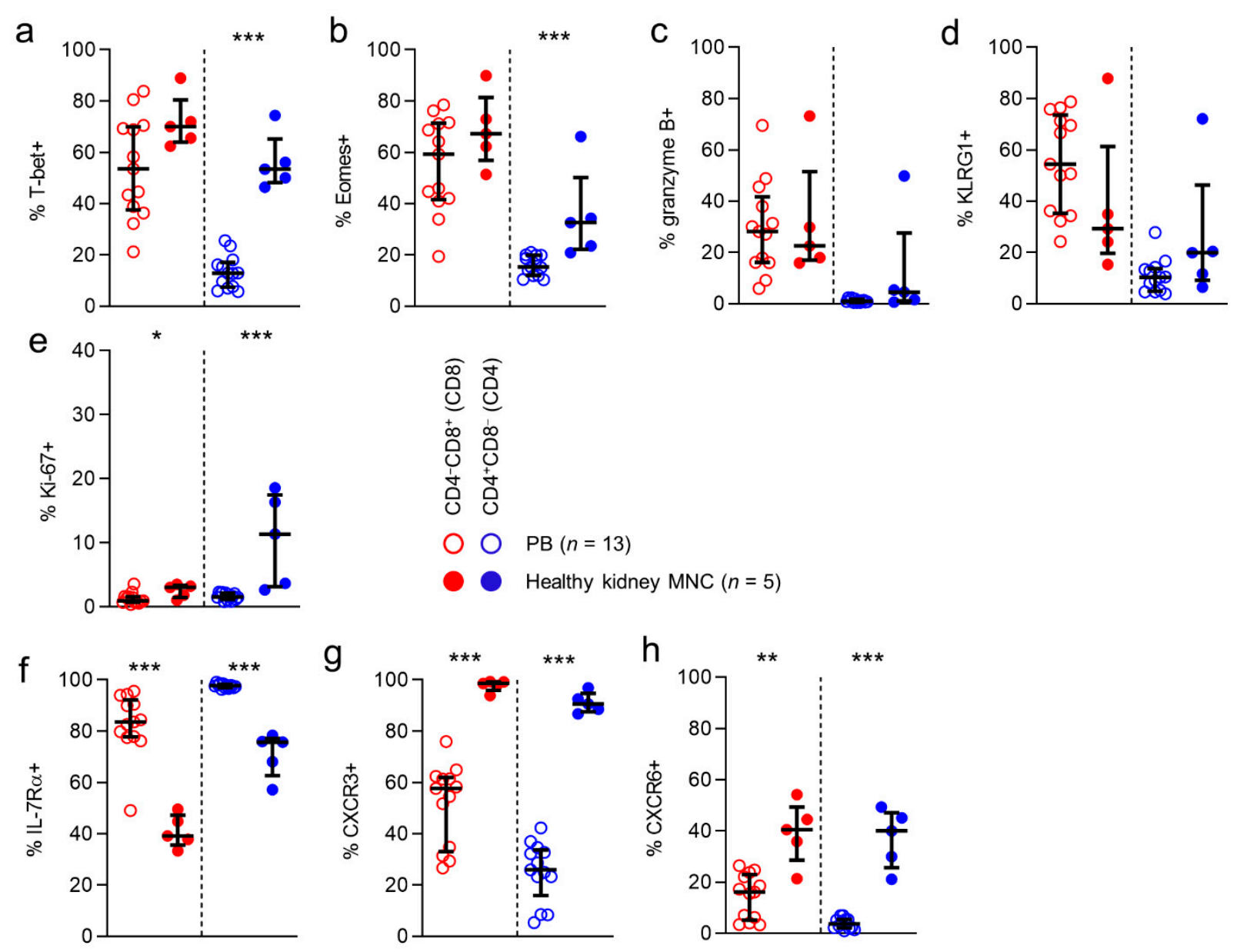

Figure 2. CD8 and CD4 T cells in kidney tissue are nearly all CXCR3-positive.(a-h) Comparison of expression of T-bet (a), Eomes (b), granzyme B (c) KLRG1 (d), ki-67 (e), IL-7R $\alpha$ (f), CXCR3 (g) and CXCR6 (h) in CD8 (red) and CD4 (blue) T cells derived from peripheral blood (PB) and healthy kidney. (median with IQR in black). Mann-Whitney U-test was used for statistical comparison. Only significant $\mathrm{p}$-values are displayed: ${ }^{*} p<0.05,{ }^{* *} p \leq 0.01,{ }^{* * *} p \leq 0.001$.

Next, we investigated expression of granzyme B, a serine protease that is known to mediate apoptosis after injection into the cytoplasm by cytotoxic T cells. In line with previous reports, T-bet and granzyme B expression were detected in substantial numbers in circulating CD8 T cells (28\%). However, its expression was rare among circulating CD4 T cells ( $1 \%)$. For CD8 T cells, granzyme B expression was similar in kidney tissue and circulating populations ( $28 \%$ vs. $23 \%$ ) (Figure 2c). Interestingly, the higher T-bet and Eomes expression frequencies detected in kidney CD4 T cells did not correspond with a higher expression frequency of granzyme B in this compartment $(5 \%)$. We then looked at expression of KLRG1, a coinhibitory receptor known to be predominantly expressed by cytotoxic acute phase effector cells and effector-memory cells. KLRG1 was expressed frequently by circulating CD8 T cells ( $54 \%)$, but not by CD4 T cells (10\%). No differences were found between anatomical compartments in KLRG1 expression for CD8 or CD4 T cells. Lastly, we investigated the expression of Ki-67, a marker denoting actively cycling cells. In line with previous observations, Ki-67 expression among circulating CD8 and CD4 T cells was rare ( $1 \%$ and $2 \%$, respectively). Interestingly, among CD8 T cells, but particularly among $\mathrm{CD} 4 \mathrm{~T}$ cells, Ki-67 expression was significantly more often detected in T cells in kidney tissue ( $3 \%$ and $11 \%$, respectively) (Figure 2e).

In conclusion, $\mathrm{CD} 4 \mathrm{~T}$ cells detected in healthy human kidney tissue, but not CD8 T cells in this compartment, more frequently expressed T-bet and Eomes. However, this did not translate into a more frequent expression of granzyme B by kidney CD4 $\mathrm{T}$ cells. 
Moreover, although overall numbers of cycling cells were low, kidney tissue contained significantly more actively cycling CD8 and CD4 T cells than the circulation.

\subsection{CD8 and CD4 T Cells in Healthy Kidney Tissue are Nearly All CXCR3-Positive}

We then looked for differences in expression of other markers, typical in circulating populations of not immediately cytotoxic memory cells, as shown previously for circulating $\mathrm{T}$ cell populations. We first looked at the expression of IL-7R $\alpha$, expressed primarily on naïve and early-differentiated memory cells in the circulation, where it is involved in sustaining homeostatic proliferation $[10,12,13]$. In peripheral blood, IL-7R $\alpha$ was expressed frequently by CD8 T cells (84\%) and CD4 T cells (98\%). CD8 and CD4 T cells in healthy kidney tissue expressed this marker significantly less often than circulating $\mathrm{T}$ cells $(71 \%$ and $76 \%$, respectively) (Figure 2f).

Next, we investigated the expression of various other chemokine receptors. Interestingly, CXCR3, a chemokine receptor involved in T cell trafficking to inflamed tissues [14-17], was expressed by exceedingly large numbers of CD8 and CD4 T cells in kidney tissue $(99 \%$ and $91 \%$, respectively), and significantly less often by circulating $\mathrm{T}$ cells $(58 \%$ and $26 \%$, respectively) (Figure 2g). Finally, we determined the expression of CXCR6, known to be implicated in forming $\mathrm{T}_{\mathrm{RM}}$ populations [18-22]. While CXCR6 was expressed by only a small population of circulating CD8 T cells $(16 \%)$, and virtually not by circulating CD4 T cells, a significantly larger proportion of CD8 and CD4 T cells in kidney tissue expressed this molecule ( $40 \%$ and $40 \%$, respectively) (Figure $2 \mathrm{~h}$ ).

In conclusion, markers typically associated with a not immediately differentiated state in the circulation, like IL-7R $\alpha$, CCR7, CD28, and CD27, were significantly less often expressed by kidney CD8 and T cells when compared to those in blood. In contrast, kidney T cells more often expressed CXCR6 and almost always expressed CXCR3.

\subsection{Distinctions in Phenotype between Healthy Kidney and Allograft T Cells Are Minimal}

Next, we wanted to investigate whether these findings remained standing in tissue from transplanted kidney allografts that were obtained for various clinical indications (Table 1).

With regard to the numbers of CD8 and CD4 T cells in healthy and allograft tissue, no differences were seen (Figure 3a). However, we noticed a nonsignificant trend towards more CD4 T cells, and less CD8 T cells in healthy tissue than in allograft tissue (Figure 3b). Additionally, when looking at CD69/CD103 expression and CD45RA/CCR7/CD28/CD27defined subsets, no differences in distribution of CD69/CD103- or CD45RA/CCR7/CD28/ CD27-defined subsets were noted, regardless of CD8/CD4 phenotype (Figure $3 \mathrm{~d}$ and Figure S5). When examining expression frequencies of the markers more typical for cytotoxic circulating T cells, we found no differences in expression of T-bet, KLRG1 or granzyme $B$ between healthy kidney or allograft $\mathrm{T}$ cells (Figure 3a,g,h). We did find that Eomes expression was seen less frequently in allograft tissue CD4 T cells, than in healthy tissue $T$ cells (Figure 3f). No differences in the expression of the other markers were observed. (Figure $3 \mathrm{i}-\mathrm{l}$ and Figure S5b-d).

In conclusion, apart from a lower expression frequency of Eomes among allograft CD4 $\mathrm{T}$ cells, cell populations did not differ between study populations. 

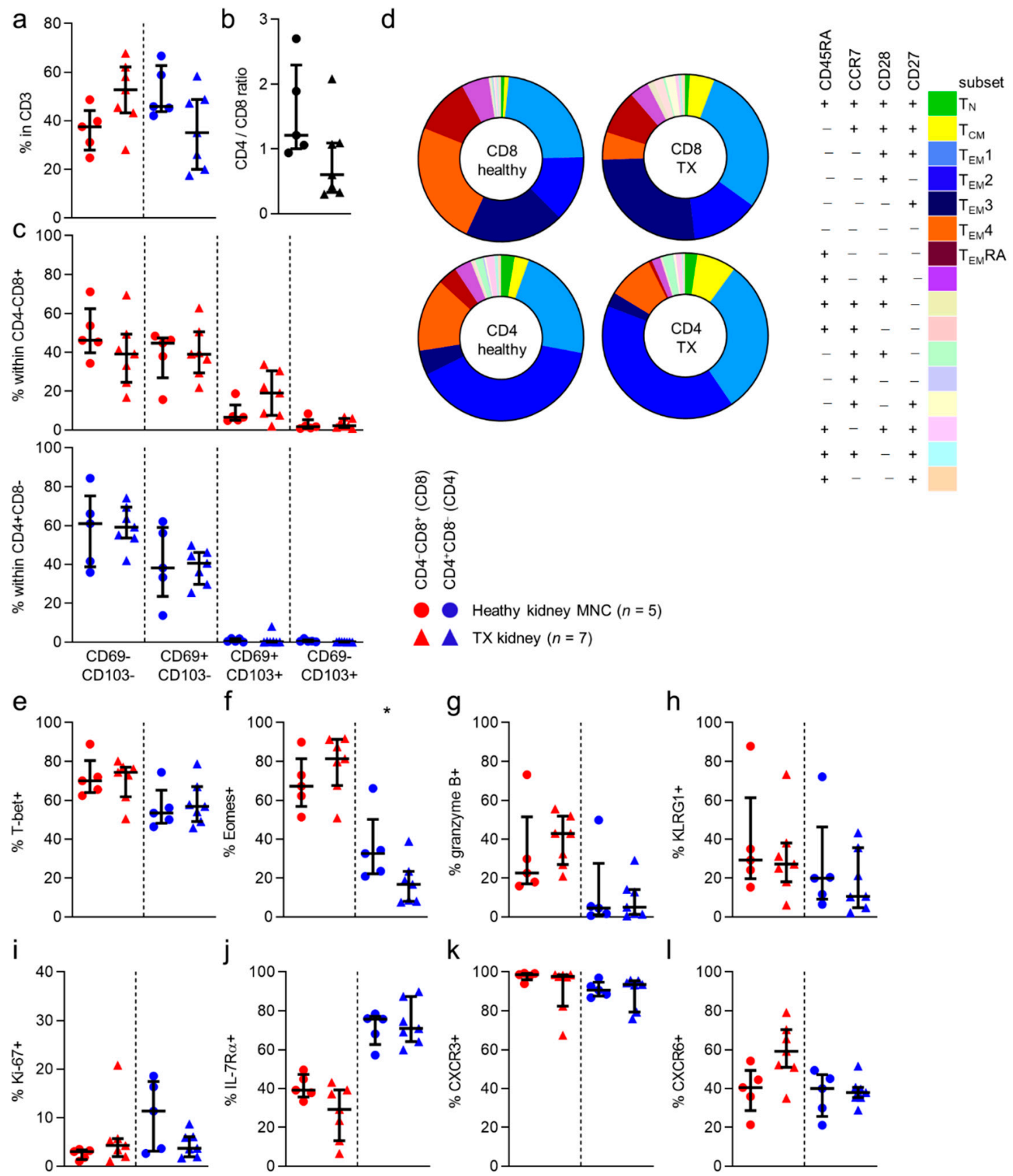

Figure 3. No differences in phenotype between healthy kidney and allograft T cells.(a) Percentage of CD4 ${ }^{-} \mathrm{CD} 8^{+}(\mathrm{CD} 8)$ and $\mathrm{CD}^{+} \mathrm{CD}^{-}(\mathrm{CD} 4) \mathrm{T}$ cells within $\mathrm{CD}^{+} \mathrm{CD}^{-} 5^{+}$single-cell live lymphocytes from healthy kidney compared to transplanted (TX) kidney (median with IQR in black). (b) CD4/CD8 ratio within PB and healthy kidney-derived T cells. (c) Distribution of CD69/CD103 based subsets within CD8 and CD4 T cells (median with IQR in black) derived from healthy and TX kidney (median with IQR in black). (d) Expression patterns of CD27, CD45RA, CCR7 and CD28 within CD8 and CD4 T cells from healthy kidney and TX (transplanted) kidney (median). (e-1) Comparison of expression of T-bet (e), Eomes (f), granzyme B (g), KLRG1 (h), ki-67 (i), IL-7R $\alpha(\mathbf{j})$, CXCR3 (k) and CXCR6 (1) in CD8 (red) and CD4 (blue) T cells derived from healthy kidney and TX kidney (median with IQR in black). Mann-Whitney U-test was used for statistical comparison. Only significant $p$-values are displayed: ${ }^{*} p<0.05$.

\section{6. $C D 69^{-} \mathrm{CD} 103^{-} \mathrm{T}$ Cells in Kidney Tissue Are Different from Circulating T Cells}

Given the similar phenotypic makeup of CD8 and CD4 T cells found in healthy kidney-tissue and in kidney allograft tissue, we pooled data from both study groups to further examine characteristics of these cells according to CD69 and CD103 expression. 
Since $\mathrm{CD} 69^{-} \mathrm{CD} 103^{+}$cells were always detected in very low frequencies ( $<50$ events), we excluded these cells from further analyses.

First, we investigated differences in these subsets according to CD69/CD103 coexpression in kidney $\mathrm{T}$ cell populations (Figure 4 and Figure S6). Interestingly, for both CD8 and CD4 T cells, substantial differences were noted in the distribution of CD45RA/CCR7/CD28/CD27-defined subsets among CD69 ${ }^{-} \mathrm{CD} 103^{-}, \mathrm{CD} 9^{+} \mathrm{CD} 103^{-}$, and $\mathrm{CD} 9^{+} \mathrm{CD} 103^{+}$subsets. For $\mathrm{CD} 8 \mathrm{~T}$ cells, $\mathrm{CD} 69^{-} \mathrm{CD} 103^{-}$cells contained a sizeable population of $\mathrm{T}_{\mathrm{EM}}$ RA cells (21\%) that was much smaller among the CD69+CD103- and $\mathrm{CD} 69^{+} \mathrm{CD} 103^{+}$subsets $(5.8 \%$ and $2.2 \%$, respectively). Instead, these latter populations contained much larger $\mathrm{T}_{\mathrm{EM}} 3\left(13 \%, 30 \%\right.$, and $32 \%$, respectively) and $\mathrm{T}_{\mathrm{EM}} 4(8 \%, 19 \%$, and $33 \%$, respectively) subpopulations. For CD4 T cells, few $\mathrm{T}_{\mathrm{EM}} \mathrm{RA}$ cells were seen among $\mathrm{CD} 9^{-} \mathrm{CD} 103^{-}, \mathrm{CD} 9^{+} \mathrm{CD} 103^{-}$, and $\mathrm{CD} 69^{+} \mathrm{CD} 103^{+}$subsets $(2.6 \%, 0 \%$, and $1.7 \%$, respectively). Instead, these cells held large subpopulations of $\mathrm{T}_{\mathrm{EM}} 1(26 \%, 24 \%$, and $10 \%$, respectively) and $\mathrm{T}_{\mathrm{EM}} 2$ cells $\left(30 \%, 46 \%\right.$, and $27 \%$, respectively). Among $\mathrm{CD} 69^{+} \mathrm{CD} 103^{-}$and particularly among the $\mathrm{CD} 69^{+} \mathrm{CD}_{103^{+}}$cells, a much larger $\mathrm{T}_{\mathrm{EM}} 4$ subpopulation was seen $(6 \%, 11 \%$ and $34 \%$, respectively).
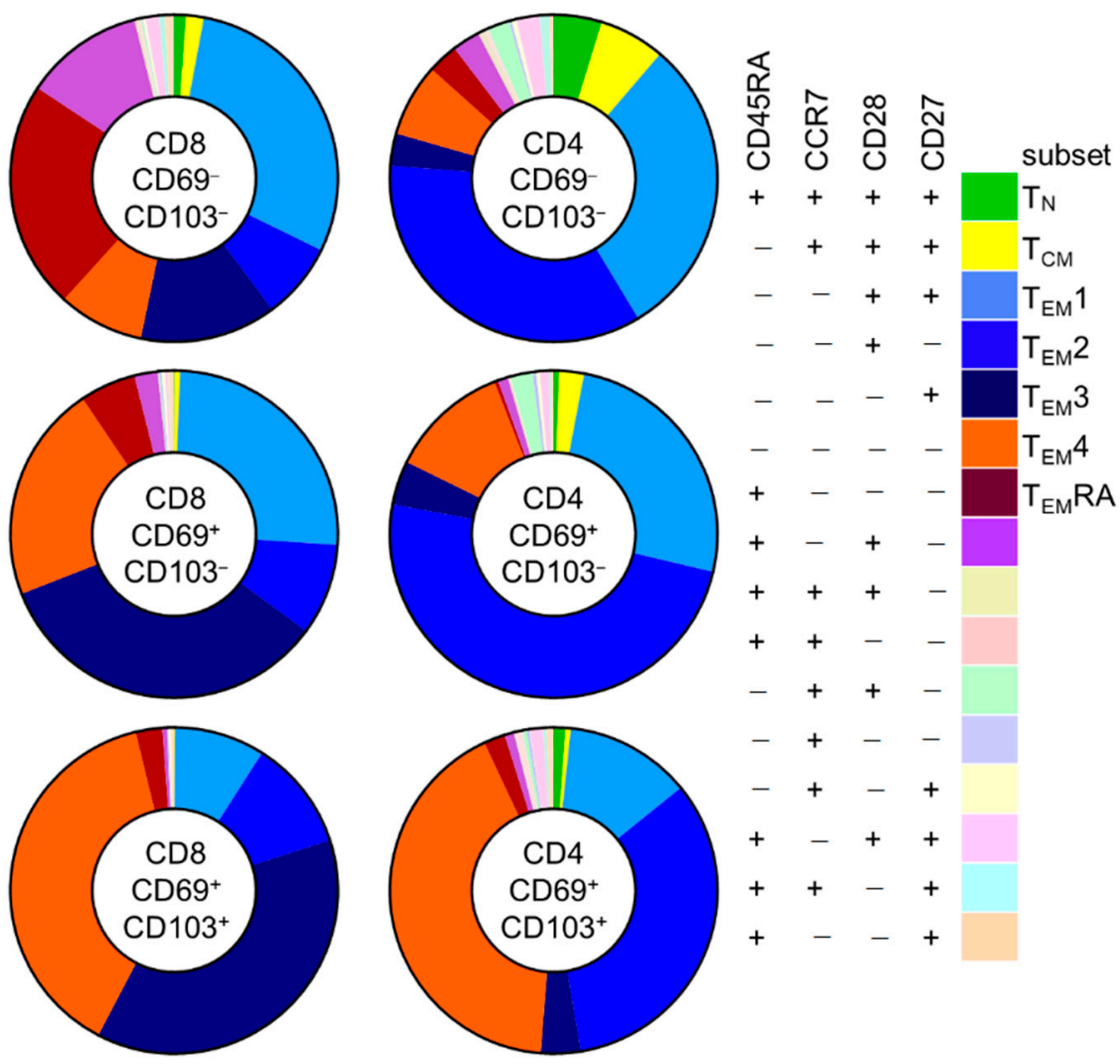

Figure 4. Memory-subset composition within CD4 and CD8 T cells from kidney changes upon CD69/CD103 co-expression. Expression patterns of CD45RA, CCR7, CD28 and CD27 within in $\mathrm{CD}^{-} 9^{-} \mathrm{CD} 103^{-}, \mathrm{CD} 9^{+} \mathrm{CD} 103^{-}$and $\mathrm{CD} 69^{+} \mathrm{CD} 103^{+}$subsets within $\mathrm{CD} 8$ and $\mathrm{CD} 4 \mathrm{~T}$ cells from kidney (median).

Given these distinctions, and the previous observation that kidney $\mathrm{T}$ cell populations barely comprised $\mathrm{T}_{\mathrm{N}}$ and $\mathrm{T}_{\mathrm{CM}}$ cells, we further investigated the $\mathrm{CD} 69^{-} \mathrm{CD} 103^{-}$cells found in kidney tissue in order to determine to what extent these cells were not just circulating cells passing through the kidney circulation. In order to do so we compared these cells to circulating cells. CD69- ${ }^{-} D 103^{-}$cells in kidney tissue differed significantly from those in the circulation: T-bet, Ki-67 and CXCR3 were expressed more often by kidney T cells, regardless of CD8/CD4 phenotype (Figure 5a-c). In contrast, IL-7R $\alpha$, CCR7, CD28, and CD27 were all expressed significantly less frequently by $\mathrm{CD} 69^{-} \mathrm{CD} 103^{-}$kidney $\mathrm{T}$ cells, 
regardless of CD8/CD4 phenotype (Figure $5 \mathrm{~d}-\mathrm{g}$ ). $\mathrm{CD}^{-} 9^{-} \mathrm{CD} 103^{-} \mathrm{CD} 4 \mathrm{~T}$ cells in kidney tissue expressed KLRG1 significantly more often than in blood and CD69-CD103- CD8 T cells in kidney tissue expressed Eomes significantly more often than in blood.
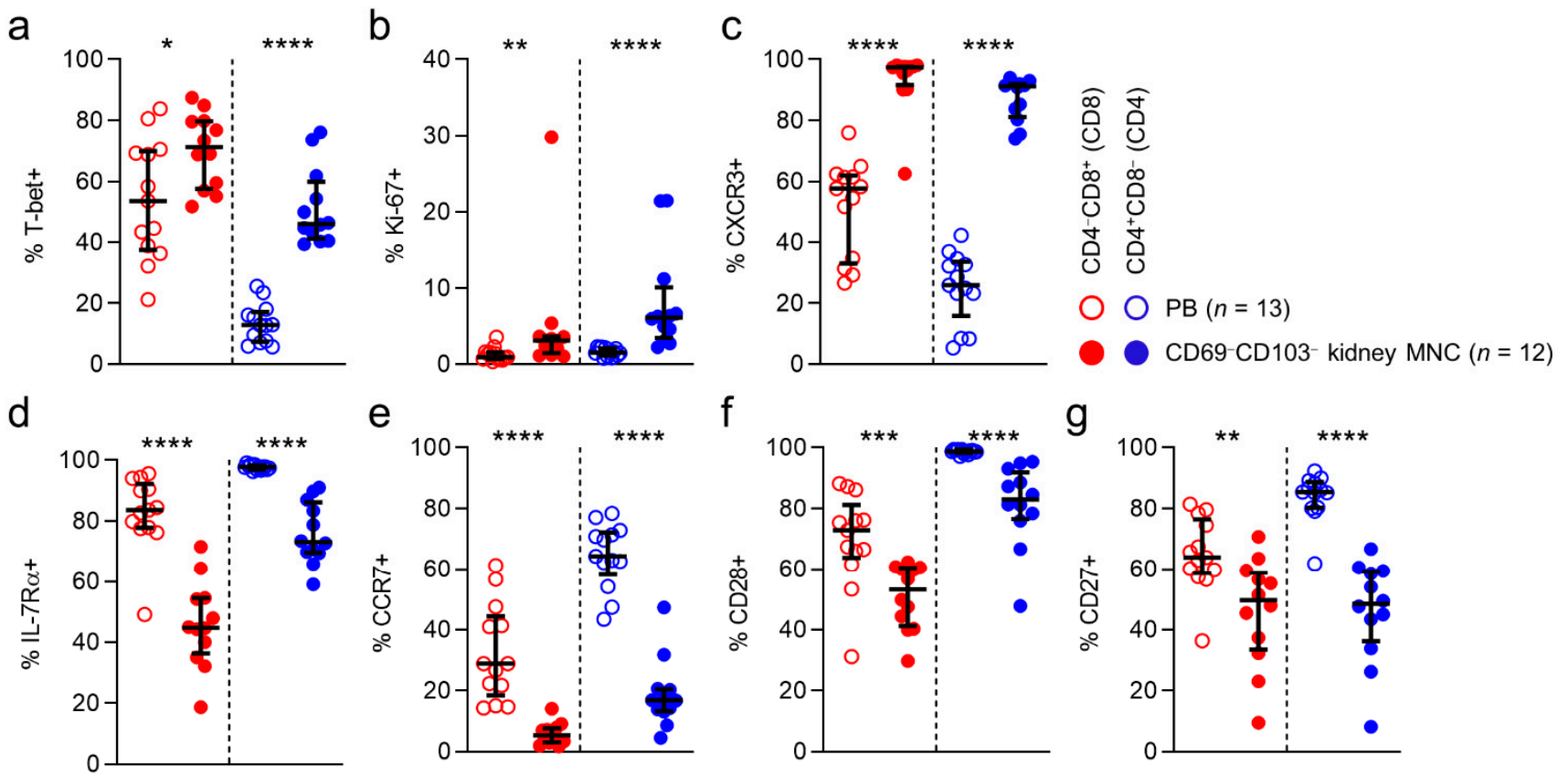

e
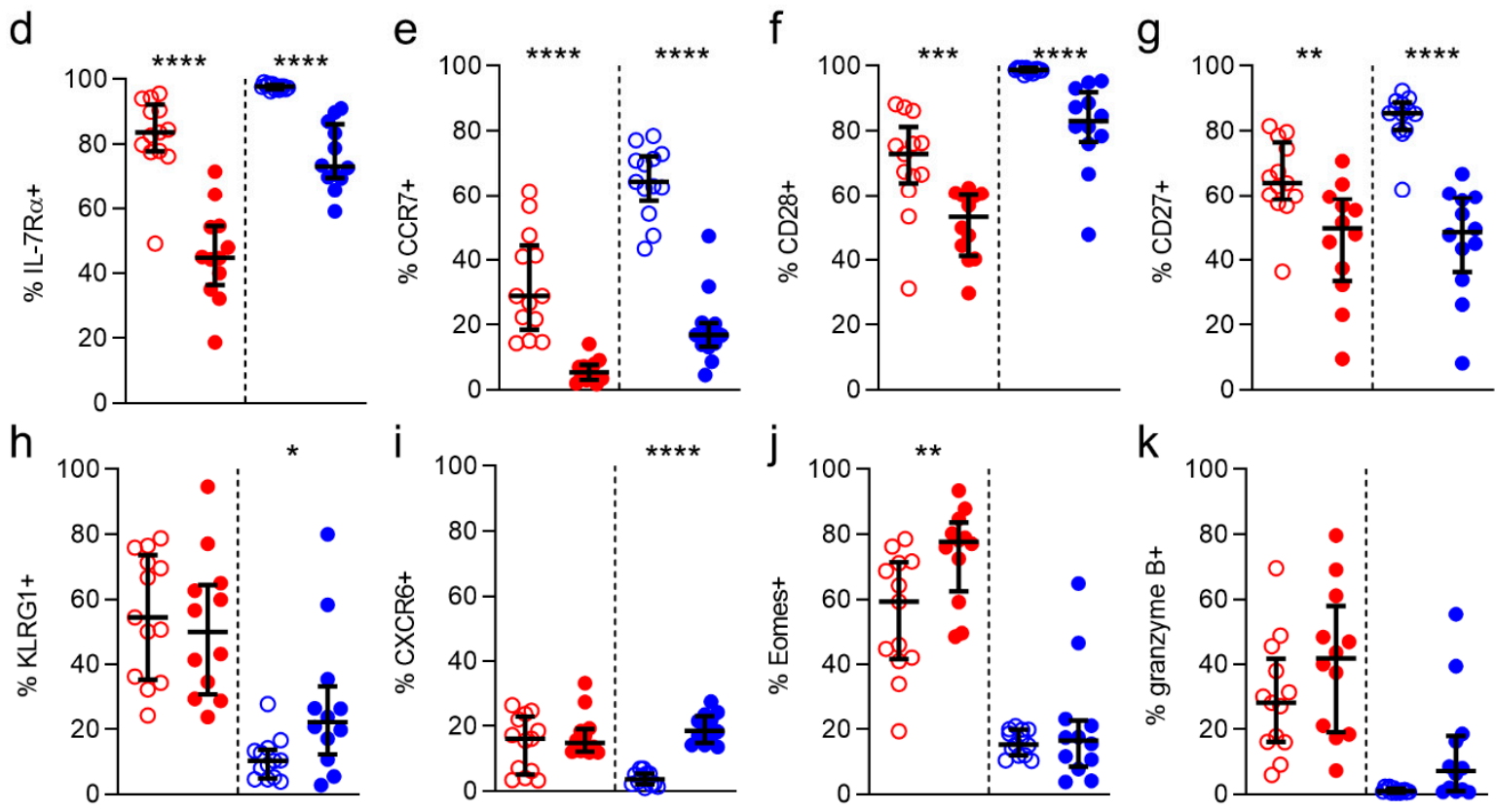

Figure 5. $\mathrm{CD}^{-} 9^{-} \mathrm{CD}_{103}^{-} \mathrm{T}$ cells in kidney tissue differ substantially from cells in the circulation. Comparison of expression of T-bet (a), ki-67 (b), CXCR3 (c), IL-7R $\alpha$ (d), CCR7 (e), CD28 (f), CD27 (g), KLRG1 (h), CXCR6 (i), Eomes (j) and granzyme B (k) in CD8 (red) and CD4 (blue) in peripheral blood (PB)-derived T cells and kidney-derived CD69- ${ }^{-}$D103 ${ }^{-} \mathrm{T}$ cells (median with IQR in black). Mann-Whitney U-test was used for statistical comparison. Only significant $\mathrm{p}$-values are displayed: ${ }^{*} p<0.05,{ }^{* *} p \leq 0.01,{ }^{* * *} p \leq 0.001,{ }^{* * * *} p \leq 0.0001$.

Next, we wanted to see how CD69 and CD103 coexpression affected markers of functional potential. First, we looked at markers associated with cytotoxic potential. Although differences were noted between individual subpopulations, no consequent patterns were seen for T-bet and Eomes in CD8 T cells when CD69 or CD103 were coexpressed (Figure $6 \mathrm{a}, \mathrm{b}$ ). In contrast, in CD4 $\mathrm{T}$ cells these transcription factors both increased together with CD69 and CD103 coexpression (Figure 6a,b). When looking at KLRG1, we noticed that for CD8 T cells, KLRG1 expression declined together with CD69/CD103 coexpression. For $\mathrm{CD} 4 \mathrm{~T}$ cells a similar trend was seen. However, here only $\mathrm{CD} 69^{-} \mathrm{CD} 103^{-}$cells expressed KLRG1 at a higher frequency than $\mathrm{CD} 9^{+} \mathrm{CD} 103^{-}$and $\mathrm{CD}^{-} 9^{+} \mathrm{CD}^{-103^{+}}$cells (Figure 6c). Expression frequencies of granzyme $\mathrm{B}$ also declined together with markers of tissue-residency, with its expression frequency being lowest amongst $\mathrm{CD} 69^{+} \mathrm{CD} 103^{+}$cells, within both $\mathrm{CD} 8$ and CD4 T cells (Figure 6d). Expression of Ki-67, which was higher amongst kidney T cells when compared to T cells in blood, did not differ according to CD69 or CD103 coexpression (Figure 6e). 


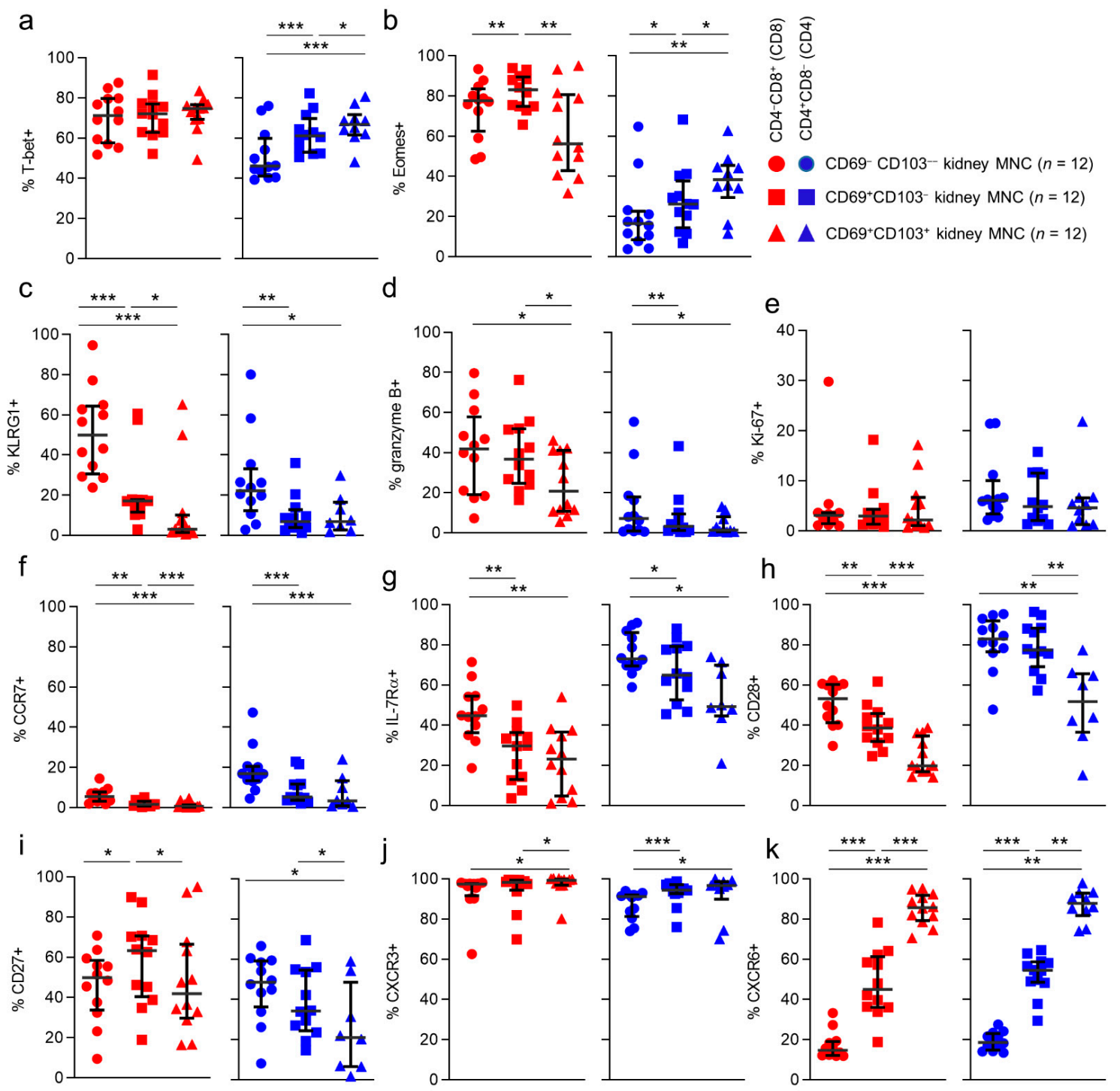

Figure 6. CXCR6 is consistently more often expressed by cells coexpressing CD69 and CD103. (a-k) Comparison of expression of T-bet (a), Eomes (b), KLRG1 (c), granzyme b (d), ki-67 (e), CCR7 (f), IL-7R $\alpha$ (g), CD28 (h), CD27 (i), CXCR3 (j) and CXCR6 (k) in $\mathrm{CD}^{-} 9^{-} \mathrm{CD} 103^{-}, \mathrm{CD} 9^{+} \mathrm{CD} 103^{-}$and $\mathrm{CD} 69^{+} \mathrm{CD} 103^{+}$subsets within CD8 (red) and CD4 (blue) T cells derived from kidney (median with IQR in black). Wilcoxon signed rank test was used for statistical comparison. Only significant $\mathrm{p}$-values are displayed: ${ }^{*} p<0.05,{ }^{* *} p \leq 0.01,{ }^{* * *} p \leq 0.001$.

We then investigated markers normally associated with a noncytotoxic memory profile according to CD69/CD103 coexpression. Expression of IL-7R $\alpha$, CCR7, and CD28 was highest within the $\mathrm{CD} 69^{-} \mathrm{CD} 103^{-}$populations, with a trend in declining expression along with coexpression of CD69/CD103 (Figure 6f-h). We then looked at expression of CXCR3 and CXCR6. Both chemokine receptors were most often expressed by CD69 ${ }^{+} \mathrm{CD} 103^{+}$cells, regardless of CD8/CD4 phenotype and showed an upward trend with coexpression of CD69/CD103. Only for CXCR6 this trend was statistically significant, affecting both CD8 and CD4 T cells (Figure 6j,k).

In conclusion, $\mathrm{CD}^{-} 9^{-} \mathrm{CD}^{-} 3^{-}$cells in kidney tissue differ substantially from cells in the circulation and may concern another $\mathrm{T}_{\mathrm{RM}}$ population not marked by CD69 or CD103 expression. The only marker that differed consistently, regardless of CD8/CD4 phenotype, in terms of CD69 and CD103 coexpression, was CXCR6. 


\section{7. $T$ Cells in Kidney Tissue More Often Produce Interferon- $\gamma$ than $T$ Cells in Blood}

Finally, we investigated cytokine production capacity by CD8/CD4-defined T cell populations in kidney tissue. First, we compared production of interferon- $\gamma($ IFN $\gamma)$, tumor necrosis factor $\alpha$ (TNF $\alpha)$, interleukin-2 (IL-2), granulocyte-macrophage colony stimulating factor (GM-CSF), and IL-17 by stimulated CD8/CD4-defined T cell populations found in blood to those in healthy kidney tissue (Figure 7a-e). Interestingly, only IFN $\gamma$ was consistently expressed by a greater proportion of $\mathrm{T}$ cells in healthy kidney tissue, when compared to T cells in blood, regardless of CD8/CD4 phenotype (Figure 7a). Differences were also noticed on an individual subset level. Specifically, TNF $\alpha$ and GM-CSF were more frequently produced by CD4 T cells in kidney tissue (Figure $7 \mathrm{~b}, \mathrm{c}$ ). With regard to polyfunctionality (i.e., the number of simultaneously produced cytokines), CD4 T cells in kidney tissue were found to be more polyfunctional than CD4 cells in blood (Figure 7f).
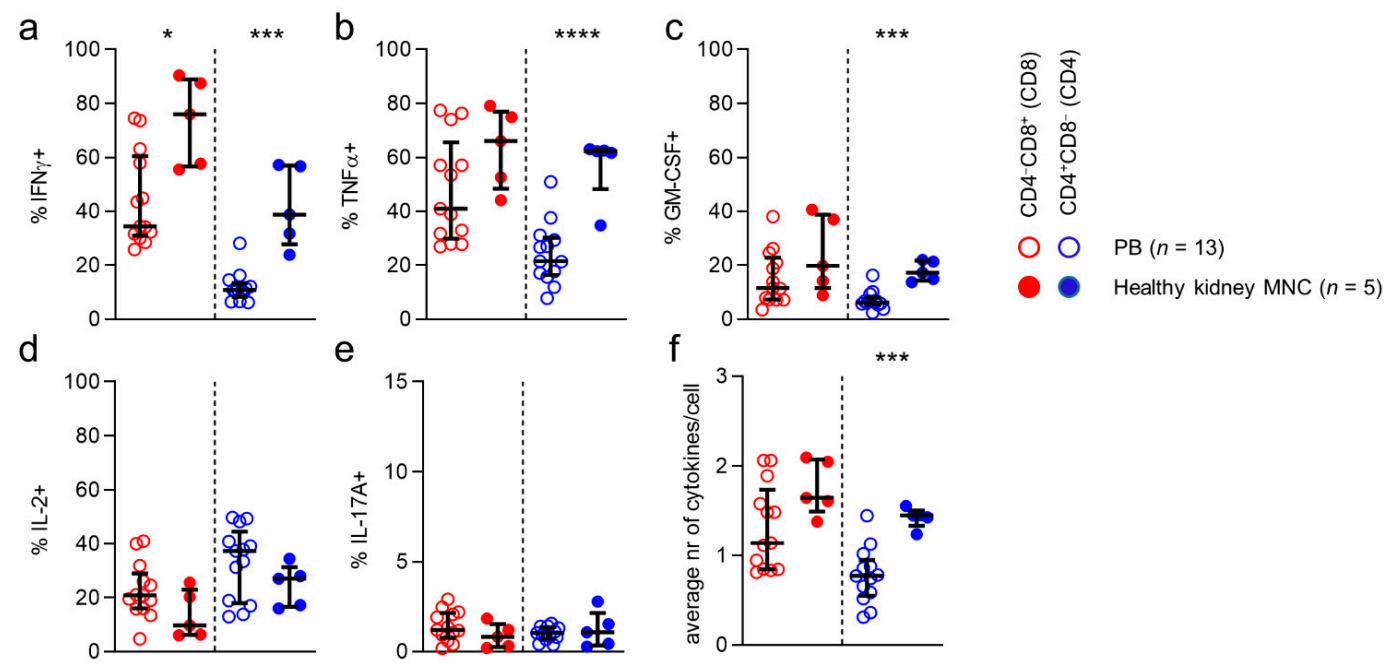

Healthy kidney MNC $(n=5)$
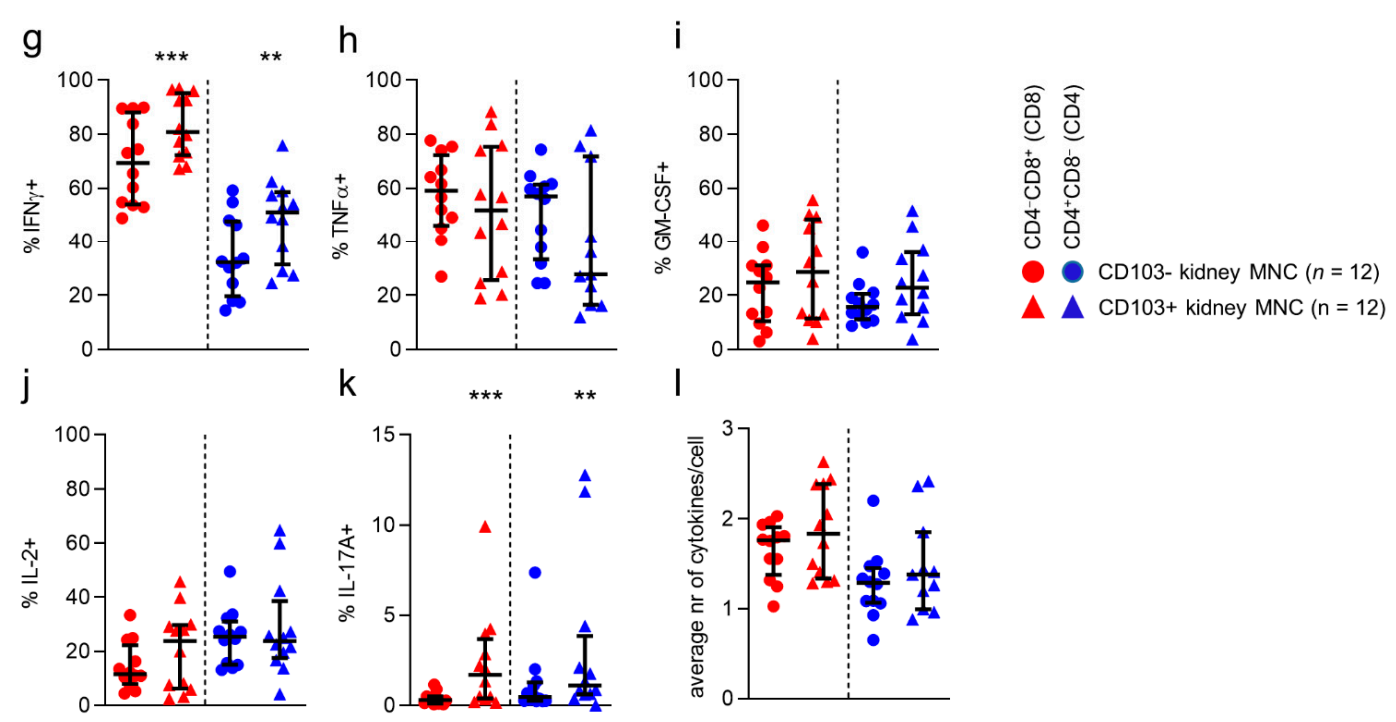

Figure 7. CD4 T cells in kidney tissue are more often polyfunctional than their counterparts in blood. (a-e) Percentage of IFN $\gamma-(\mathbf{a})$, TNF $\alpha-(\mathbf{b})$, GM-CSF-(c), IL-2-(d) and IL-17A-(e) producing CD8 (red) and CD4 (blue) T cells derived from peripheral blood (PB) and healthy kidney after $4 \mathrm{hr}$ stimulation with PMA and ionomycin (median with IQR in black). (f) The average number of cytokines produced by CD8 and CD4 T cells derived from PB and healthy kidney (median with IQR in black). (g-k) Percentage of IFN $\gamma-(\mathbf{a})$, TNF $\alpha-(\mathbf{b})$, GM-CSF-(i), IL-2-(j) and IL-17A-(k) producing CD103- ${ }^{-}$and CD103 ${ }^{+}$CD8 (red) and CD4 (blue) T cells derived from kidney after $4 \mathrm{hr}$ stimulation with PMA and ionomycin (median with IQR in black). (1) The average number of cytokines produced by CD103- and CD103+ CD8 and CD4 T cells derived from kidney (median with IQR in black). Statistical comparisons used: (a-d) Mann-Whitney U-test (e,f) Wilcoxon signed rank test. Only significant $\mathrm{p}$-values are displayed: ${ }^{*} p<0.05,{ }^{* *} p \leq 0.01,{ }^{* * *} p \leq 0.001$. 
Next, we looked at differences in cytokine production capacity between stimulated T cells from healthy and allograft tissue. No differences in production of individual cytokines, or in number of simultaneously produced cytokines were detected between $\mathrm{T}$ cells from healthy or allograft kidney tissue (Figure S7).

Since CD69 is expressed upon stimulation of T cells, we only studied the difference between CD103-negative and CD103-expressing CD4 and CD8 T cells (Figure 7g-1). When comparing CD4 and CD8 T cells expressing CD103 with cells not expressing CD103 in kidney tissue, we noticed that CD8 and CD4 CD103 ${ }^{+}$cells expressed more IFN $\gamma$ than $\mathrm{CD} 103^{-}$cells (Figure 7g). Additionally, although IL-17A-producing cells were low among $\mathrm{CD}_{103}{ }^{+} \mathrm{CD} 8$ and CD4 T cells in kidney tissue, they were consistently found more frequently in this population compared to the $\mathrm{CD}_{103^{-}}$population.

In conclusion, more $\mathrm{T}$ cells in kidney tissue produced IFN $\gamma$ when compared to circulating $\mathrm{T}$ cells, regardless of CD8/CD4 phenotype. Indeed, the highest percentage of IFN $\gamma$-producing cells was found among the CD103-expressing CD4 and CD8 kidneyderived $\mathrm{T}$ cells. In addition, $\mathrm{T}$ cells in kidney allografts did not differ from those in healthy kidney tissue with respect to these parameters.

\section{Discussion}

In the current study we addressed the diversity of $\mathrm{T}$ cell subsets, according to expression of CD8 and CD4, and the markers of tissue-residency, CD69 and CD103, in human kidneys and compared to these to blood.

Substantial numbers of CD8 and CD4 T cells were indeed detected in kidney tissue. Furthermore, these $\mathrm{T}$ cells in kidneys contained considerable numbers of $\mathrm{CD} 69^{+} \mathrm{CD} 103^{-}$ cells. CD69+CD103+ cells were also detected, but predominantly among the CD8 T cells and were virtually nonexistent among CD4 T cells. A similar finding concerned lung $\mathrm{T}_{\mathrm{RM}}$ previously [23]. As expected, such CD69 and CD103-expressing populations were instead near absent from the circulation. A striking difference when comparing $\mathrm{T}$ cells in kidney with those in blood, concerned a distinct distribution of the traditional CD45RA/CCR7/CD28/CD27-defined subsets. Interestingly, expression of CD28 was more often not expressed when T cells were coexpressing CD69 alone or in combination with CD103. Theoretically, this should render these populations less susceptible to costimulatory signals by CD80 and CD86. Other differences concerned a higher expression frequency of CXCR3, CXCR6, and Ki-67. Additionally, kidney T cells more often contained IFN $\gamma$ producing cells and were frequently polyfunctional. Indeed, within the kidney, CD103+ $\mathrm{T}_{\mathrm{RM}} \mathrm{s}$ contained more IFN $\gamma$-producing cells than their CD103-negative counterparts. In addition, $\mathrm{CD}_{103^{+}} \mathrm{T}$ cells more often produced IL-17, although this concerned a modest population.

With regard to the more frequent expression of CXCR3 by CD8 and CD4 kidney T cells, the CXCR3/CXCL10 axis was previously shown to be involved in the shaping of $T_{R M}$ populations in skin, liver, and lymphoid tissue [24-28]. Additionally, it is involved in the trafficking to stressed epithelium and inflammation in a general sense [14-17]. Given the high frequencies of CXCR3 among these T cells in healthy kidney tissue, CXCR3 appears to be implicated in $\mathrm{T}_{\mathrm{RM}}$ homeostasis in kidney tissue as well and may not necessarily involve inflammation or danger signals to do so. With regard to CXCR6, the CXCR6/CXCL16 axis has indeed already been shown to be essential for trafficking of $T_{R M}$ to different compartments like the lungs, skin, liver, and brain, and may concern a universal mechanism essential for guiding and retaining $\mathrm{T}_{\mathrm{RM}}$ to and in tissues, also concerning $\mathrm{T}_{\mathrm{RM}}$ in human kidney tissue [18-22].

Farber and coworkers have extensively characterized and compared CD8 and CD4 $\mathrm{T}_{\mathrm{RM}}$ populations residing in different human tissue types derived from organ donors. They described how TRM populations in lung, spleen, small intestines, and various secondary lymphoid tissues differ with regard to transcriptome, but also to expression of various proteins, including cytokines, investigated in the current study [29-31]. However, these investigations did not comprise TRM populations in the human kidney, and data on this 
subject is scarce. We previously showed that CD8 T cells targeting polyomavirus BK VP1 and LTAG proteins, deriving from a virus that has a strong tropism for renal epithelial cells, are detectable in allograft kidneys. These virus-specific T cells expressed CD69 and CD103 in higher numbers than their counterparts found in the circulation of the same patients. Furthermore, these $\mathrm{T}$ cells generally expressed a CD45RA ${ }^{-} \mathrm{CD} 27^{-}$granzyme B-negative phenotype [5]. Later, others have also reported on $\mathrm{T}_{\mathrm{RM}}$ populations in human kidney tissue obtained from transplant nephrectomies. In this publication, the authors report that $\mathrm{T}$ cells in these tissues mainly concerned CD8 T cells [32]. We instead found that CD4 T cells, in fact, comprised the largest $T$ cell subset. However, we also found that the balance shifted, although not significantly, towards greater numbers of CD8 T cells in allograft tissue when compared to healthy kidney tissue. As such, this discrepancy might be explained by a different study group, and it may be that in health, the immunological defense is more focused on extracellular threats, like bacteria, versus more intracellular threats, like viruses and cancer in the immunocompromised hosts. We did not find other differences in the markers studied, between healthy kidney and allograft $\mathrm{T}$ cells. However, further research, using techniques with a broader view on transcriptome, like RNA sequencing, or proteome, like mass spectrometry, should be employed to establish whether this is indeed the case.

In addition, de Leur et al. describe how $\mathrm{T}_{\mathrm{RM}}$ in kidney frequently expressed granzyme $B$, while we detected only low amounts of granzyme B in both healthy and allograft kidney tissue [32]. However, we did detect substantial T-bet and Eomes-expressing T cells in kidney tissue, which in circulating $\mathrm{T}$ cell populations, is normally indeed associated with a higher expression of granzyme B [10]. While the latter may not be surprising, given the fact that granzyme B expression is also directly induced by T-bet [33,34], this association was not apparent among kidney $\mathrm{T}$ cells in the current study. As we and others have shown that also human lung-, brain-, and skin-derived $\mathrm{T}_{\mathrm{RM}}[25,26,35,36]$, as well as kidney-derived tissue resident MAIT cells $[6,7]$ are low in their granzyme B content, while often expressing substantial amounts of T-bet and Eomes, this might be a common trait of (human) $\mathrm{T}_{\mathrm{RM}}$. Furthermore, in lung $\mathrm{T}_{\mathrm{RM}}$ granzyme $\mathrm{B}$ expression was seen to be rapidly upregulated upon stimulation [35], suggesting that this might also occur in other $\mathrm{T}_{\mathrm{RM}}$. Here, the authors hypothesized that such 'hidden cytotoxicity' serves to protect the structural integrity of tissues from damage by cytotoxic $\mathrm{T}$ cells.

In conclusion, we show that $\mathrm{T}$ cells in kidney tissue are present in substantial numbers and comprise populations that frequently express $\mathrm{CD}_{6} 9^{+}$and $\mathrm{CD}_{103}{ }^{+}$, molecules by which $\mathrm{T}$ cells adhere to, and persist in, tissues. Nevertheless, the $\mathrm{CD}^{-} 9^{-} \mathrm{CD} 103^{-} \mathrm{T}$ cells in kidney tissue appear to be distinct from circulating $\mathrm{T}$ cells and may concern another distinct $\mathrm{T}_{\mathrm{RM}}$ population, possibly persisting in kidneys by other mechanisms yet to be unveiled. Another option may be that these $\mathrm{CD} 69^{-} \mathrm{CD} 103^{-} \mathrm{T}$ cells concern a population that have only recently egressed from the circulation, and have only transiently acquired new phenotypic traits due to an interaction with the kidney microenvironment. Further investigations into this population are needed to elucidate these possibilities. Furthermore, CD8 and CD4 kidney T cells, were often actively cycling and more frequently expressed CXCR6. Additionally, CD8 and CD4 populations displayed a particularly high expression of CXCR3, strongly implicating these chemokine receptors, as well as CXCR6 in $T_{R M}$ accrual and persistence in human kidneys. Therefore, further investigations are needed to enhance our image of $\mathrm{T}_{\mathrm{RM}}$ populations in the human kidney. Nevertheless, the findings presented here form a solid first step towards more detailed characterization of $\mathrm{T}$ cell populations in kidney tissue and their role in health and disease.

Supplementary Materials: The following are available online at https:/ / www.mdpi.com/2073-4 409/10/2/288/s1, Table S1: Monoclonal antibodies used for phenotyping, Table S2: Monoclonal antibodies used for stimulation assay, Figure S1: Gating strategy T cell phenotyping, Figure S2: Gating strategy polyfunctional assay, Figure S3: CD3 cell counts, Figure S4: Phenotype of CD8 and CD4 T cells derived from PB and healthy kidney, Figure S5: CD27/CD45RA/CCR7/CD28-expression profile and phenotype of CD8 and CD4 T cells from healthy kidney compared to TX kidney, Figure S6: 
Phenotype of CD69/CD103 based subsets in CD8 and CD4 T cells derived from kidney, Figure S7: Cytokines produced by healthy kidney compared to TX kidney derived CD8 and CD4 T cells.

Author Contributions: Conceptualization, E.B.M.R. and M.C.v.A.; methodology, E.B.M.R.; validation, C.v.d.P., E.B.M.R., N.D.v.d.B. and M.C.v.A.; formal analysis, C.v.d.P., E.B.M.R. and M.L.T.; investigation, C.v.d.P., E.B.M.R., M.L.T. and N.D.v.d.B.; resources, N.D.v.d.B.; F.J.B., E.B.M.R. and J.K. data curation, E.B.M.R.; writing—original draft preparation, C.v.d.P., M.C.v.A.; writing—review and editing, C.v.d.P., E.B.M.R., M.L.T., N.D.v.d.B., J.K., I.J.M.t.B., S.E.G., R.A.W.v.L., F.J.B. and M.C.v.A.; visualization, E.B.M.R.; supervision, I.J.M.t.B., S.E.G., R.A.W.v.L., F.J.B. and M.C.v.A.; project administration, F.J.B. and S.E.G.; funding acquisition, M.C.v.A. and F.J.B. All authors have read and agreed to the published version of the manuscript.

Funding: This research was funded by Astellas Pharma and the Dutch Kidney Foundation (18OKG22)

Institutional Review Board Statement: The study was conducted according to the guidelines of the Declaration of Helsinki, and approved by the Ethics Committee of the Amsterdam UMC, location AMC (protocol code 2016_045; 1 April 2016).

Informed Consent Statement: Informed consent was obtained from all subjects involved in the study. Additionally, residual tissue from patients who underwent tumor nephrectomy (kidney tissue distant from the tumor) was donated by the Department of Pathology and also stored in the Biobank. These tissues were processed anonymously according to the Federation of Dutch Medical Scientific Societies' Code of Conduct (Hu-man Tissue and Medical Research: Code of Conduct for Responsible Use, 2011 www.federa.org).

Data Availability Statement: All data is contained within the article or supplementary material. Raw data are available on request.

Acknowledgments: We would like to thank A.M. O'Byrne for English editing the paper, R. Bakridi for his help with optimizing the stimulation assay and K. van der Pant, M.D., T. Standaar, T. Pulskensde Jong, A. Molenaar, and J. van de Geest-van Zoest for their help with participant inclusion. We would also like to thank all participants for contributing to this study.

Conflicts of Interest: The authors declare no conflict of interest.

\section{Abbreviations}

For a full list of abbreviations and acronyms see Supplementary Materials.

\section{References}

1. Masopust, D.; Soerens, A.G. Tissue-Resident T Cells and Other Resident Leukocytes. Annu Rev. Immunol 2019, 37, 521-546. [CrossRef] [PubMed]

2. van Aalderen, M.C.; Remmerswaal, E.B.; ten Berge, I.J.; van Lier, R.A. Blood and beyond: Properties of circulating and tissueresident human virus-specific alphabeta CD8(+) T cells. Eur. J. Immunol. 2014, 44, 934-944. [CrossRef] [PubMed]

3. Carlson, C.M.; Endrizzi, B.T.; Wu, J.; Ding, X.; Weinreich, M.A.; Walsh, E.R.; Wani, M.A.; Lingrel, J.B.; Hogquist, K.A.; Jameson, S.C. Kruppel-like factor 2 regulates thymocyte and T-cell migration. Nature 2006, 442, 299-302. [CrossRef] [PubMed]

4. Mackay, L.K.; Minnich, M.; Kragten, N.A.; Liao, Y.; Nota, B.; Seillet, C.; Zaid, A.; Man, K.; Preston, S.; Freestone, D.; et al. Hobit and Blimp1 instruct a universal transcriptional program of tissue residency in lymphocytes. Science 2016, 352, 459-463. [CrossRef] [PubMed]

5. $\quad$ van Aalderen, M.C.; Remmerswaal, E.B.; Heutinck, K.M.; Ten Brinke, A.; Feltkamp, M.C.; van der Weerd, N.C.; van der Pant, K.A.; Bemelman, F.J.; van Lier, R.A.; Ten Berge, I.J. Clinically Relevant Reactivation of Polyomavirus BK (BKPyV) in HLA-A02-Positive Renal Transplant Recipients Is Associated with Impaired Effector-Memory Differentiation of BKPyV-Specific CD8+ T Cells. PLoS Pathog. 2016, 12, e1005903. [CrossRef]

6. Law, B.M.P.; Wilkinson, R.; Wang, X.; Kildey, K.; Giuliani, K.; Beagley, K.W.; Ungerer, J.; Healy, H.; Kassianos, A.J. Human Tissue-Resident Mucosal-Associated Invariant T (MAIT) Cells in Renal Fibrosis and CKD. J. Am. Soc. Nephrol 2019, 30, 1322-1335. [CrossRef]

7. Terpstra, M.L.; Remmerswaal, E.B.M.; van der Bom-Baylon, N.D.; Sinnige, M.J.; Kers, J.; van Aalderen, M.C.; Geerlings, S.E.; Bemelman, F.J. Tissue-resident mucosal-associated invariant T (MAIT) cells in the human kidney represent a functionally distinct subset. Eur. J. Immunol. 2020. [CrossRef] 
8. Cossarizza, A.; Chang, H.D.; Radbruch, A.; Acs, A.; Adam, D.; Adam-Klages, S.; Agace, W.W.; Aghaeepour, N.; Akdis, M.; Allez, M.; et al. Guidelines for the use of flow cytometry and cell sorting in immunological studies (second edition). Eur. J. Immunol. 2019, 49, 1457-1973. [CrossRef]

9. Lamoreaux, L.; Roederer, M.; Koup, R. Intracellular cytokine optimization and standard operating procedure. Nat. Protoc. 2006, 1, 1507-1516. [CrossRef]

10. van Aalderen, M.C.; Remmerswaal, E.B.; Verstegen, N.J.; Hombrink, P.; ten Brinke, A.; Pircher, H.; Kootstra, N.A.; ten Berge, I.J.; van Lier, R.A. Infection history determines the differentiation state of human CD8+ T cells. J. Virol. 2015, 89, 5110-5123. [CrossRef]

11. Romero, P.; Zippelius, A.; Kurth, I.; Pittet, M.J.; Touvrey, C.; Iancu, E.M.; Corthesy, P.; Devevre, E.; Speiser, D.E.; Rufer, N. Four functionally distinct populations of human effector-memory CD8+ T lymphocytes. J. Immunol. 2007, 178, 4112-4119. [CrossRef] [PubMed]

12. van Leeuwen, E.M.; de Bree, G.J.; Remmerswaal, E.B.; Yong, S.L.; Tesselaar, K.; ten Berge, I.J.; van Lier, R.A. IL-7 receptor alpha chain expression distinguishes functional subsets of virus-specific human CD8+ T cells. Blood 2005, 106, 2091-2098. [CrossRef] [PubMed]

13. Kimura, M.Y.; Pobezinsky, L.A.; Guinter, T.I.; Thomas, J.; Adams, A.; Park, J.H.; Tai, X.; Singer, A. IL-7 signaling must be intermittent, not continuous, during CD8(+) T cell homeostasis to promote cell survival instead of cell death. Nat. Immunol. 2013, 14, 143-151. [CrossRef] [PubMed]

14. Srivastava, R.; Khan, A.A.; Chilukuri, S.; Syed, S.A.; Tran, T.T.; Furness, J.; Bahraoui, E.; BenMohamed, L. CXCL10/CXCR3Dependent Mobilization of Herpes Simplex Virus-Specific CD8(+) TEM and CD8(+) TRM Cells within Infected Tissues Allows Efficient Protection against Recurrent Herpesvirus Infection and Disease. J. Virol. 2017, 91. [CrossRef] [PubMed]

15. Caldeira-Dantas, S.; Furmanak, T.; Smith, C.; Quinn, M.; Teos, L.Y.; Ertel, A.; Kurup, D.; Tandon, M.; Alevizos, I.; Snyder, C.M. The Chemokine Receptor CXCR3 Promotes CD8(+) T Cell Accumulation in Uninfected Salivary Glands but Is Not Necessary after Murine Cytomegalovirus Infection. J. Immunol. 2018, 200, 1133-1145. [CrossRef]

16. Kunkel, E.J.; Boisvert, J.; Murphy, K.; Vierra, M.A.; Genovese, M.C.; Wardlaw, A.J.; Greenberg, H.B.; Hodge, M.R.; Wu, L.; Butcher, E.C.; et al. Expression of the chemokine receptors CCR4, CCR5, and CXCR3 by human tissue-infiltrating lymphocytes. Am. J. Pathol. 2002, 160, 347-355. [CrossRef]

17. Guarda, G.; Hons, M.; Soriano, S.F.; Huang, A.Y.; Polley, R.; Martin-Fontecha, A.; Stein, J.V.; Germain, R.N.; Lanzavecchia, A.; Sallusto, F. L-selectin-negative CCR7- effector and memory CD8+ T cells enter reactive lymph nodes and kill dendritic cells. Nat. Immunol. 2007, 8, 743-752. [CrossRef]

18. Wein, A.N.; McMaster, S.R.; Takamura, S.; Dunbar, P.R.; Cartwright, E.K.; Hayward, S.L.; McManus, D.T.; Shimaoka, T.; Ueha, S.; Tsukui, T.; et al. CXCR6 regulates localization of tissue-resident memory CD8 T cells to the airways. J. Exp. Med. 2019, 216, 2748-2762. [CrossRef]

19. Zaid, A.; Hor, J.L.; Christo, S.N.; Groom, J.R.; Heath, W.R.; Mackay, L.K.; Mueller, S.N. Chemokine Receptor-Dependent Control of Skin Tissue-Resident Memory T Cell Formation. J. Immunol. 2017, 199, 2451-2459. [CrossRef]

20. Tse, S.W.; Radtke, A.J.; Espinosa, D.A.; Cockburn, I.A.; Zavala, F. The chemokine receptor CXCR6 is required for the maintenance of liver memory CD8(+) T cells specific for infectious pathogens. J. Infect. Dis. 2014, 210, 1508-1516. [CrossRef]

21. Urban, S.L.; Jensen, I.J.; Shan, Q.; Pewe, L.L.; Xue, H.H.; Badovinac, V.P.; Harty, J.T. Peripherally induced brain tissue-resident memory CD8(+) T cells mediate protection against CNS infection. Nat. Immunol. 2020, 21, 938-949. [CrossRef]

22. Fransen, N.L.; Hsiao, C.C.; van der Poel, M.; Engelenburg, H.J.; Verdaasdonk, K.; Vincenten, M.C.J.; Remmerswaal, E.B.M.; Kuhlmann, T.; Mason, M.R.J.; Hamann, J.; et al. Tissue-resident memory T cells invade the brain parenchyma in multiple sclerosis white matter lesions. Brain 2020, 143, 1714-1730. [CrossRef] [PubMed]

23. Hombrink, P.; Helbig, C.; Backer, R.A.; Piet, B.; Oja, A.E.; Stark, R.; Brasser, G.; Jongejan, A.; Jonkers, R.E.; Nota, B.; et al. Programs for the persistence, vigilance and control of human CD8(+) lung-resident memory T cells. Nat. Immunol. 2016, 17, 1467-1478. [CrossRef] [PubMed]

24. Remmerswaal, E.B.; Havenith, S.H.; Idu, M.M.; van Leeuwen, E.M.; van Donselaar, K.A.; Ten Brinke, A.; van der Bom-Baylon, N.; Bemelman, F.J.; van Lier, R.A.; Ten Berge, I.J. Human virus-specific effector-type T cells accumulate in blood but not in lymph nodes. Blood 2012, 119, 1702-1712. [CrossRef]

25. Schaerli, P.; Ebert, L.; Willimann, K.; Blaser, A.; Roos, R.S.; Loetscher, P.; Moser, B. A skin-selective homing mechanism for human immune surveillance T cells. J. Exp. Med. 2004, 199, 1265-1275. [CrossRef] [PubMed]

26. Clark, R.A.; Chong, B.; Mirchandani, N.; Brinster, N.K.; Yamanaka, K.; Dowgiert, R.K.; Kupper, T.S. The vast majority of CLA+ T cells are resident in normal skin. J. Immunol. 2006, 176, 4431-4439. [CrossRef]

27. Stelma, F.; de Niet, A.; Sinnige, M.J.; van Dort, K.A.; van Gisbergen, K.; Verheij, J.; van Leeuwen, E.M.M.; Kootstra, N.A.; Reesink, H.W. Human intrahepatic CD69 + CD8+ T cells have a tissue resident memory T cell phenotype with reduced cytolytic capacity. Sci. Rep. 2017, 7, 6172. [CrossRef]

28. Pallett, L.J.; Davies, J.; Colbeck, E.J.; Robertson, F.; Hansi, N.; Easom, N.J.W.; Burton, A.R.; Stegmann, K.A.; Schurich, A.; Swadling, L.; et al. IL-2(high) tissue-resident T cells in the human liver: Sentinels for hepatotropic infection. J. Exp. Med. 2017, 214, 1567-1580. [CrossRef]

29. Sathaliyawala, T.; Kubota, M.; Yudanin, N.; Turner, D.; Camp, P.; Thome, J.J.; Bickham, K.L.; Lerner, H.; Goldstein, M.; Sykes, M.; et al. Distribution and compartmentalization of human circulating and tissue-resident memory T cell subsets. Immunity 2013, 38, 187-197. [CrossRef] 
30. Thome, J.J.; Yudanin, N.; Ohmura, Y.; Kubota, M.; Grinshpun, B.; Sathaliyawala, T.; Kato, T.; Lerner, H.; Shen, Y.; Farber, D.L. Spatial map of human T cell compartmentalization and maintenance over decades of life. Cell 2014, 159, 814-828. [CrossRef]

31. Kumar, B.V.; Ma, W.; Miron, M.; Granot, T.; Guyer, R.S.; Carpenter, D.J.; Senda, T.; Sun, X.; Ho, S.H.; Lerner, H.; et al. Human Tissue-Resident Memory T Cells Are Defined by Core Transcriptional and Functional Signatures in Lymphoid and Mucosal Sites. Cell Rep. 2017, 20, 2921-2934. [CrossRef] [PubMed]

32. de Leur, K.; Dieterich, M.; Hesselink, D.A.; Corneth, O.B.J.; Dor, F.; de Graav, G.N.; Peeters, A.M.A.; Mulder, A.; Kimenai, H.; Claas, F.H.J.; et al. Characterization of donor and recipient CD8+ tissue-resident memory T cells in transplant nephrectomies. Sci. Rep. 2019, 9, 5984. [CrossRef] [PubMed]

33. Szabo, S.J.; Kim, S.T.; Costa, G.L.; Zhang, X.; Fathman, C.G.; Glimcher, L.H. A novel transcription factor, T-bet, directs Th1 lineage commitment. Cell 2000, 100, 655-669. [CrossRef]

34. Szabo, S.J.; Sullivan, B.M.; Stemmann, C.; Satoskar, A.R.; Sleckman, B.P.; Glimcher, L.H. Distinct effects of T-bet in TH1 lineage commitment and IFN-gamma production in CD4 and CD8 T cells. Science 2002, 295, 338-342. [CrossRef] [PubMed]

35. Piet, B.; de Bree, G.J.; Smids-Dierdorp, B.S.; van der Loos, C.M.; Remmerswaal, E.B.; von der Thusen, J.H.; van Haarst, J.M.; Eerenberg, J.P.; ten Brinke, A.; van der Bij, W.; et al. CD8(+) T cells with an intraepithelial phenotype upregulate cytotoxic function upon influenza infection in human lung. J. Clin. Investig. 2011, 121, 2254-2263. [CrossRef]

36. Smolders, J.; Heutinck, K.M.; Fransen, N.L.; Remmerswaal, E.B.M.; Hombrink, P.; Ten Berge, I.J.M.; van Lier, R.A.W.; Huitinga, I.; Hamann, J. Tissue-resident memory T cells populate the human brain. Nat. Commun. 2018, 9, 4593. [CrossRef] 